Sains Malaysiana 49(9)(2020): 2151-2158

http://dx.doi.org/10.17576/jsm-2020-4909-13

\title{
Microplastic Ingestion by Periwinkle Snail Littoraria scabra and Mangrove Crab Metopograpsus quadridentata in Pramuka Island, Jakarta Bay, Indonesia \\ (Pengingesan Mikroplastik daripada Siput Periwinkel Littoraria scabra dan Ketam Nipah Metopograpsus quadridentate di Pulau Pramuka, Teluk Jakarta, Indonesia)
}

\author{
Mufti Petala Patria*, Clara Alverina Santoso \& Nurma Tsabita
}

\begin{abstract}
Microplastic has been known to contaminate our marine environment. This research aim was to determine the abundance of microplastic in mangrove periwinkle snail Littoraria scabra and mangrove crab Metopograpsus quadridentata in Pramuka Island, Jakarta Bay, Indonesia. Pramuka Island was chosen as the research site because this island is densely populated and received waste from Jakarta Bay. Samples of mangrove snails were taken by purposive random sampling method of 10 individuals with shell lengths ranging from 1.5 to $2.7 \mathrm{~cm}$, and 9 individuals crab with circa $6 \mathrm{~cm}$ carapace wide were collected. Analysis of microplastic abundance was done by isolating microplastic in each sample. Isolation in the sample was done by dissolving tissue of animals in a 65\% nitric acid ( $\mathrm{HNO}_{3}$ ) solution for 24 h and sodium chloride $(\mathrm{NaCl})$ was added to increase density of solution. Sample was observed under microscope. The results obtained 3 types of microplastic found in the body of snail (fiber, film, and fragment) and 4 types in crab (fiber, film, fragment, and granula). Fiber has the highest percentage in snail (66.89\%) and crab (68.72\%). The average of microplastic abundance were 86.88 particles/individual in snail and 327.56 particles/individual in crab, respectively. This result indicated that the coastal area of Pramuka Island has been polluted by the microplastics. There was positive correlation between microplastic abundance and the body weight of snail $(r=0.9778)$, and body weight of crab $(r=0.9193)$.
\end{abstract}

Keywords: Fiber; Jakarta; mangrove; microplastic; snail

\section{ABSTRAK}

Mikroplastik telah dikenali sebagai bahan pencemar kepada laut kita. Kajian ini bertujuan untuk menentukan jumlah mikroplastik pada siput periwinkel Littoraria scabra dan ketam nipah Metopograpsus quadridentata di Pulau Pramuka, Teluk Jakarta, Indonesia. Pulau Pramuka dipilih dalam kajian ini kerana pulau ini berpenduduk padat dan menerima limpahan sampah dari kota Jakarta. Sampel siput periwinkle diambil secara kaedah persampelan tujuan rawak sebanyak 10 individu dengan panjang cangkerang 1.5-2.7 cm dan 9 individu ketam nipah dengan lebar karapas sekitar $6 \mathrm{~cm}$. Analisis mikroplastik dijalankan dengan proses isolasi mikroplastik pada setiap sampel. Isolasi dalam sampel dijalankan dengan melarutkan tisu haiwan pada larutan asid nitrik ( $\mathrm{HNO}_{3}$ ) 65\% dan natrium klorida ( $\mathrm{NaCl)} \mathrm{ditambah}$ untuk meningkatkan ketumpatan larutan. Sampel diperhati di bawah mikroskop. Keputusan kajian yang diperoleh menunjukkan 3 jenis mikroplastik yang ditemui dalam badan siput (fiber, filem dan serpihan) dan 4 jenis ditemui dalam ketam (fiber, filem, serpihan dan butiran). Bahan fiber merupakan peratus tertinggi di dalam siput (66.89\%) dan ketam (68.72\%). Purata mikroplastik terkumpul adalah 86.88 zarah/individu dalam siput dan 327.56 zarah/individu dalam ketam. Keputusan kajian menunjukkan bahawa kawasan pesisir di Pulau Pramuka telah dicemari dengan mikroplastik. Terdapat korelasi positif antara mikroplastik terkumpul dan berat badan siput ( $r=0.9778)$ serta berat badan ketam $(r=0.9193)$.

Kata kunci: Gentian; Jakarta; mikroplastik; paya bakau; siput

\section{INTRODUCTION}

Marine debris becomes a serious problem that is being faced by the entire world community, including other organisms. Marine debris is generally the result of human activities in the form of solid materials that are intentionally or unintentionally disposed in the marine environment (CSIRO 2014). The dominant type of waste in the ocean is plastic (Dias \& Lovejoy 2012). In smaller sizes, microplastic is the most common measure of plastic waste 
found in the ocean (Tanaka \& Takada 2016). Microplastic is a plastic synthetic polymer particle that have variations in chemical composition, size (ranging from 1 - 5 $\mathrm{mm}$ ), density, and shape (Andrady 2011). Microplastic originates from the degradation (plastic objects into smaller fragments) (Andrady 2011; Cole et al. 2013). Fragmentation of plastics in the ocean occurred through photodegradation, the effects of physical degradation, as well as other processes, and produces large amounts of plastic particles. In addition to several factors mentioned, plastic waste is also easily fragmented if the density is low. Low density plastics caused floating plastics and are exposed directly to UV and air (Teuten 2009).

Microplastic as waste is divided into two based on the source, namely primary and secondary microplastic. Primary microplastic is in the form of grains of plastic particles that have been produced in small size. Meanwhile, secondary microplastic is the result of fragmentation of larger plastics (Tanaka \& Takada 2016). Primary microplastic waste sources for example came from beauty products, and generally made of polymers such as polyethylene, polystyrene, and polypropylene (Gregory 1996). Secondary microplastic waste sources came from industrial raw materials, household waste, fishing nets, synthetic fibers, and other weathering products of plastic products. Most type of microplastic waste in the ocean are secondary microplastic (Tanaka \& Takada 2016).

Pramuka Island is located in the cluster of Seribu Islands, Jakarta, and it is highly vulnerable to be contaminated by marine debris such as plastic. This was proven during the collection of garbage from the coastal areas around Pramuka Island, Panggang Island, and Karya Island which was as much as $142 \mathrm{~kg}$, and $69 \%$ of the total waste was plastic waste (Kementerian Koordinator Maritim 2017). According to the source, the waste in the Seribu Islands comes from the inhabitants of the archipelago itself and from outside the island. (Sahwan 2004). Based on research conducted by LIPI Oceanographic Research Center, Seribu Islands receive debris through 13 rivers that empties into the Jakarta Bay (LIPI 2009).

Plastic waste from Jakarta Bay is spread through the flow of water and food chain, therefore, it can get to the cluster of Seribu Islands. Microplastic can pollute the environment and disturb the health of marine biota if ingested. Lots of marine animals that could contaminated with microplastics includes protists, zooplankton, annelids, echinodermata, cnidarian, amphipod, decapod, isopod, bivalve, mollusc, cephalopod, barnacle, sea turtle, bird, and fish (Andrady 2011). Some of the animals that lived in mangroves ecosystems such as small fish, zooplankton, bivalve, snail and crab could be contaminated with microplastics too (Green 2016).
Marine biota can feed on microplastic both directly and through the food chain by eating smaller biota that already contained microplastic (Dias \& Lovejoy 2012). With its small size, microplastic can be accidentally ingested by marine organisms. For example, microplastic pellets can carry heavy metals such as $\mathrm{Cd}, \mathrm{Co}, \mathrm{Cr}, \mathrm{Cu}$, $\mathrm{Ni}$, and $\mathrm{Pb}$ (Holmes 2013). If microplastic particles accumulated in large amounts in the body of a snail or crab, then the microplastic can clog the digestive tract thus blocking the absorption of nutrients (Browne et al 2013; Wright 2013).

Mangrove periwinkle snail Littoraria scabra and mangrove crab Metopograpsus quadridentata are the important gastropods and crustacean in the mangrove ecosystem. Mangrove snails have a grazer diet, therefore this species has an important role in the food chain in the mangrove ecosystem (Tupan 2009), whereas the crab belongs to omnivore benthic fauna. The purpose of this research was to investigate microplastic abundance in mangrove periwinkle snail, mangrove crab and the correlation between microplastic abundance and body weight of each biota in mangrove ecosystem at Pramuka Island. The two animals are indeed not eaten by humans, but they are as a link between lower-level consumers and those above, because the predators of these animals are cephalopods and fish.

\section{MATERIALS AND METHODS}

\section{LOCATION AND TIME}

Data was collected at mangrove area, south side of Pramuka Island, Seribu Islands, Jakarta Bay, on April 14,2018 , with location coordinate $5^{\circ} 44^{\prime} 54.5$ 'S $106^{\circ}$ 36'50.4" E (Figure 1). The samples were processed at Marine Biology Laboratory, Department of Biology, Universitas Indonesia, Depok.

\section{METHODS}

Samples of mangrove snails L. scabra and mangrove crab $M$. quadridentata were taken by a purposive random sampling method. Ten mangrove snails with relatively the same size (shell length $1.5-2.7 \mathrm{~cm}$ ) and nine mangrove crab $M$. quadridentata were collected from the mangrove area. Furthermore, the samples were immersed in a glass bottle containing $70 \%$ alcohol.

The snail and crab samples were weighed. The body tissue of snail was insulated from the inside of the shell using tweezers. The snail and crab body tissue were destroyed using $3 \mathrm{~mL}$ of $\mathrm{HNO}_{3}(65 \%)$ solution (ratio of snails and $\mathrm{HNO}_{3}$ 1:5) in beaker glass, covered with aluminium foil, then placed for $24 \mathrm{~h}$ in the acid chamber. The result of the bath was diluted 10 times using 


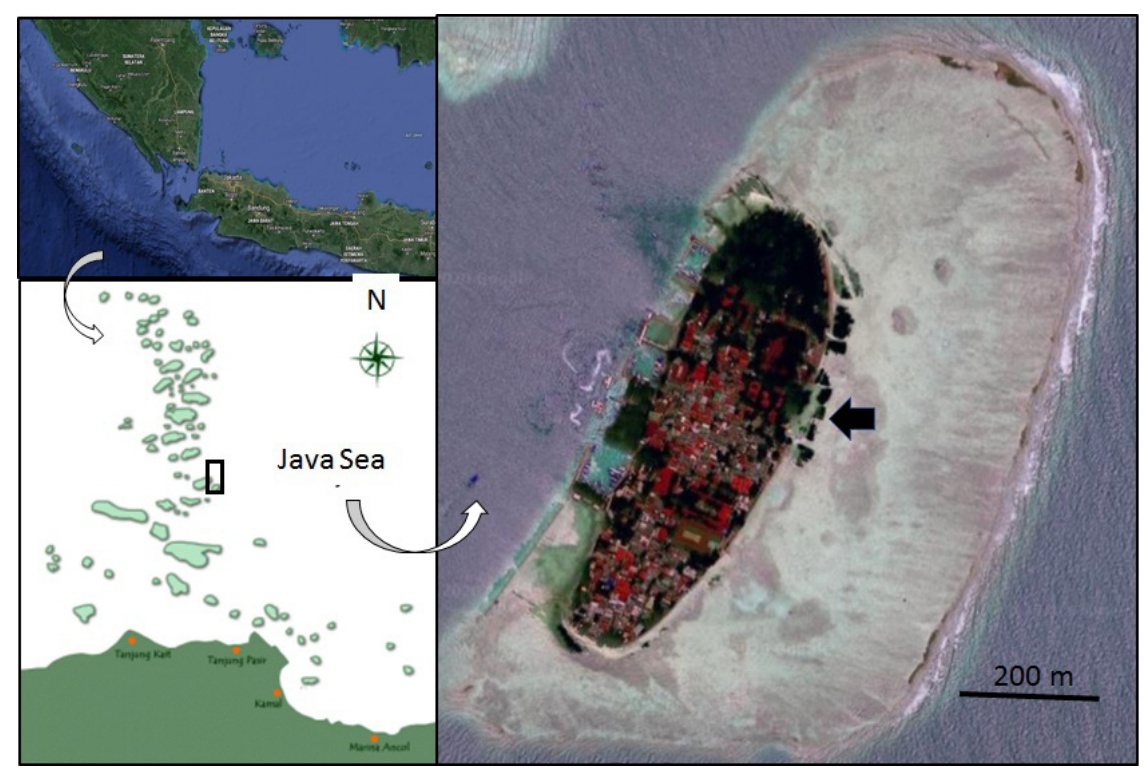

FIGURE 1. Pramuka Island in Jakarta Bay and location of sample collection (white arrow) (modification from Google map)

aquadest and $\mathrm{NaCl}$ was added until the solution becomes saturated. $1 \mathrm{~mL}$ of resulted dilution were then pipetted into the counting chamber and then analyzed under a microscope to determine the presence and abundance of microplastic. Type of microplastic was grouped into fiber, film, fragment and granula (Ningrum \& Patria 2019).

The data that have been obtained were then analyzed using the correlation and regression equation formula (MS Excel) to determine the correlation between microplastic abundance in biota and the body weight.

\section{RESULTS AND DISCUSSION}

TYPE AND AMOUNT OF MICROPLASTIC

Fiber, film, and fragment of microplastic were found in the periwinkle snails, while fiber, film, fragment, and granula were recorded in the mangrove crab. The highest percentage of microplastic type in snail was fiber $(66.89 \%)$ followed by film $(32.45 \%)$ and fragment $(0.66)$ type (Table $1 \&$ Figure 2 ). The composition of microplastic type was no different in crabs (Table 2 \& Figure 3), and the highest percentage recorded was the fiber $(68.72 \%)$.

TABLE 1. Abundant of microplastic in periwinkle snail L. scabra

\begin{tabular}{lcccccc}
\hline \multirow{2}{*}{ Samples } & \multirow{2}{*}{$\begin{array}{c}\text { Body } \\
\text { weight }\end{array}$} & \multicolumn{5}{c}{ Abundant of microplastic in snail } \\
\cline { 3 - 7 } & & Fiber & Film & Fragment & Total & particles/g \\
\hline & 1.2 & 80 & 35 & 1 & 116 & 96.67 \\
2 & 1 & 41 & 50 & 1 & 92 & 92.00 \\
3 & 0.6 & 40 & 11 & 0 & 51 & 85.00 \\
4 & 0.7 & 40 & 27 & 0 & 67 & 95.71 \\
5 & 1 & 55 & 30 & 1 & 86 & 86.00 \\
6 & 1 & 68 & 30 & 0 & 98 & 98.00 \\
7 & 0.6 & 28 & 12 & 1 & 41 & 68.33 \\
8 & 0.8 & 52 & 19 & 0 & 71 & 88.75 \\
9 & 0.6 & 29 & 9 & 0 & 38 & 63.33 \\
10 & 1 & 72 & 22 & 1 & 95 & 95.00 \\
Total & 8.5 & 505 & 245 & 5 & 755 & 868.80 \\
Average & 0.85 & 50.5 & 24.5 & 0.5 & 75.5 & 86.88 \\
$\%$ & & 66.89 & 32.45 & 0.66 & 100 & \\
\hline
\end{tabular}




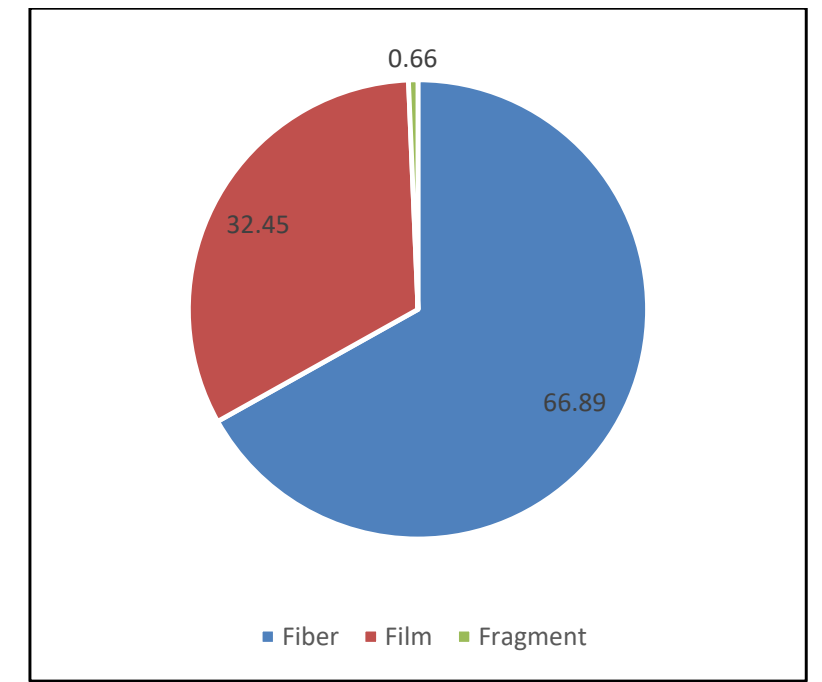

FIGURE 2. Composition of microplastic type (\%) in the periwinkle snail L. scabra

The average of microplastic abundance in the snail and crab were 75.5 and 327.56 particles/individual, respectively. If the data were presented in particle per gram body weight, we found for the snail 86.88 particles $/ g$ and for the crab 33 particles/g (Tables $1 \& 2$ ).
The microplastic abundance increases along with increasing body weight of biota. We used the regression correlation analysis, the result showed (Figures 4 \& $5)$, there were significant positive correlation between microplastic abundance with the body weight of snail $(\mathrm{r}=0.9770)$ and body weight of crab $(\mathrm{r}=0.9139)$.

TABLE 2. Abundance of microplastic in mangrove crab M. quadridentata

\begin{tabular}{|c|c|c|c|c|c|c|c|}
\hline \multirow{3}{*}{ Samples } & \multirow{3}{*}{$\begin{array}{c}\text { Body } \\
\text { weight }\end{array}$} & \multicolumn{6}{|c|}{ Abundant of microplastic in Crab } \\
\hline & & \multicolumn{5}{|c|}{ particles/ind } & \multirow[t]{2}{*}{ particles/g } \\
\hline & & Fiber & Film & Fragment & Granula & Total & \\
\hline 1 & 8,36 & 170 & 198 & 3 & 4 & 375 & 44,86 \\
\hline 2 & 8,63 & 262 & 57 & 5 & 0 & 324 & 37,54 \\
\hline 3 & 7,59 & 153 & 82 & 3 & 5 & 243 & 32,02 \\
\hline 4 & 18,94 & 386 & 179 & 1 & 0 & 566 & 29,88 \\
\hline 5 & 11,3 & 272 & 57 & 5 & 0 & 334 & 29,56 \\
\hline 6 & 14,03 & 455 & 75 & 0 & 9 & 539 & 38,42 \\
\hline 7 & 6,95 & 78 & 69 & 1 & 3 & 151 & 21,73 \\
\hline 8 & 7,42 & 154 & 87 & 3 & 11 & 255 & 34,37 \\
\hline 9 & 5,63 & 96 & 61 & 0 & 4 & 161 & 28,60 \\
\hline Total & & 2026 & 865 & 21 & 36 & 2948 & 296,96 \\
\hline Average & & 225,11 & 96,11 & 2,33 & 4,00 & 327,56 & 33,00 \\
\hline$\%$ & & 68,72 & 29,34 & 0,71 & 1,22 & 100,00 & \\
\hline
\end{tabular}




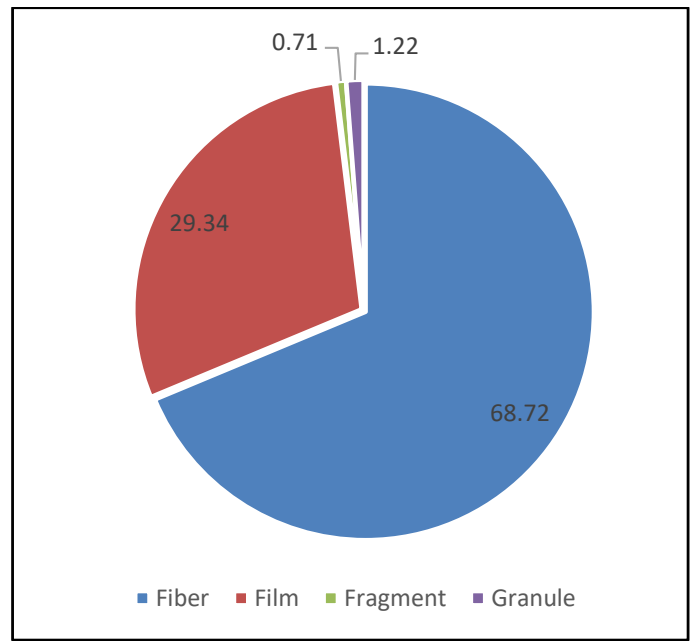

FIGURE 3. Composition of microplastic type (\%) in the mangrove crab M. quadridentata

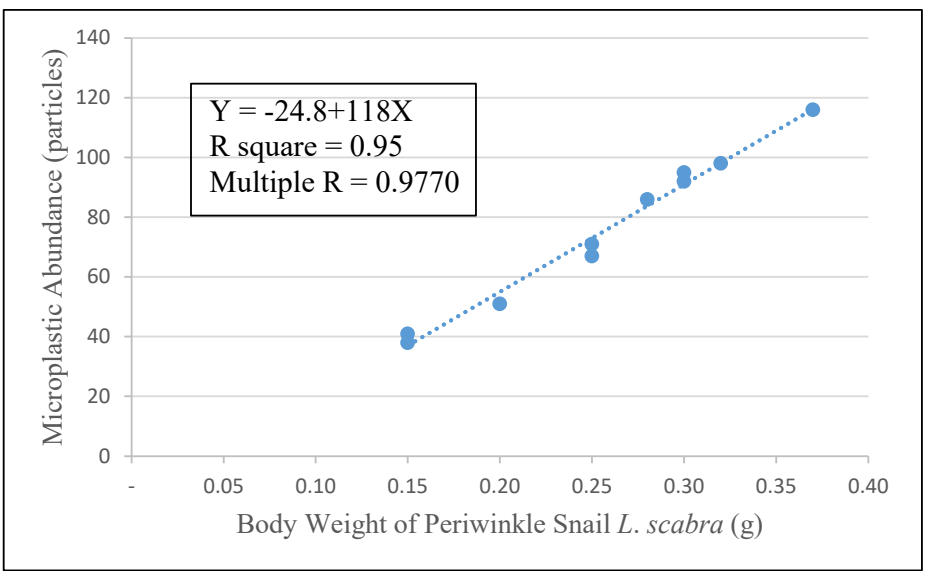

FIGURE 4. Linear regretion of microplastic abundance with body weight of periwinkle snail L. scabra

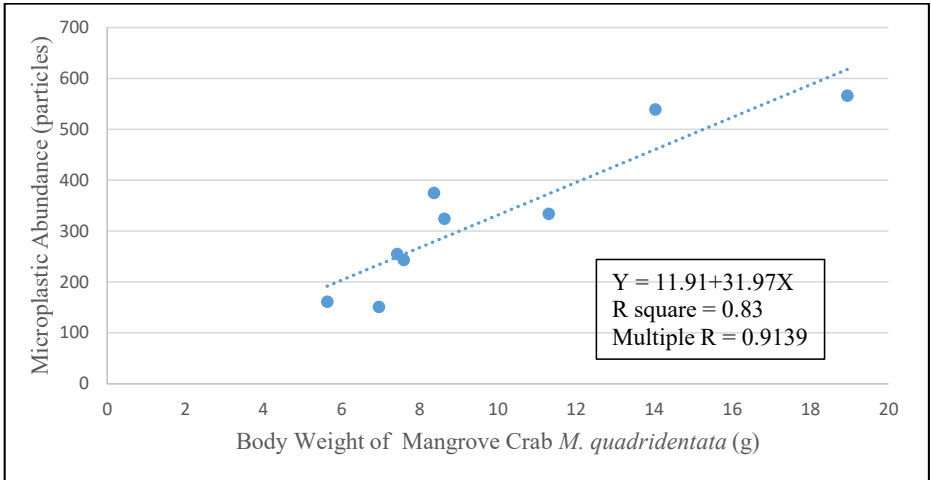

FIGURE 5. Linear regression of microplastic abundance with body weight of mangrove crab M. quadridentata $(\mathrm{g})$ 


\section{DISCUSSION}

We found four types of microplastics in the crab samples, namely fibers, fragments, films, and granules, although in snail samples, we did not find granules type. Fiber was the most dominant microplastic type found in the snail and crab. Fiber is a degradable plastic waste in the form of yarn or fiber. Generally, fiber comes from fishing lines and ship mines as well as synthetic fibers (Pirc et al. 2016). Pramuka Island is a densely populated island and active as an ecotourism area makes a lot of activities that can be done such as snorkeling or cruising the island by boat and fishing. The fibers type of microplastic known could be released from textiles and garments such as clothes (Pirc et al. 2016). The fiber are known to remain for a longer period of time on the surface of the water because of their relatively low densities while fragments and granules with higher densities tend to sink (Lie et al. 2018). Moreover, the films type of microplastics found in sample could be from degradation and fragmentation plastic debris such as plastic bottles, plastic bags, and plastic bowl (Sahwan 2004).

According to Alfaro (2007), the periwinkle snail $L$. scabra can digest many variations of food sources such as foliose macrophyte, filament algae, mangrove tree tissue, microalgae, bacterial, and zooplankton. This shows the microplastic that goes into the body of the mangrove snail through the food intermediaries it obtains. For example, snails eat zooplankton and microalgae that contaminated by microplastic. The microplastic can easily enter into the body of the snail because of its small size, making it difficult to distinguish the food particles (Browne et al. 2011). Some informations about the microplastic abundance in the snail in Indonesia was published. The mangrove snail Cerithidea obtusa in Pangkal Babu, Jambi, Sumatera, contained 167 particles microplastic/individual (Fitri \& Patria 2019). Al-Hamra and Patria (2019) reported that microplastic abundance in the gonggong snail Laevistrombus turturella in Bintan Island, Riau Islands was between 360 - 628 particles/individual. Our results showed the mangrove snail L. scabra contained lower microplastic abundance, because the size of the snail was smaller than the other references. The larger the animal, the more microplastic it contains, which can be seen in Figure 4.

The presence of microplastics in mangrove crab $M$. quadridentata very influenced by the surrounding condition in its habitat and depends on what it was consumed. Known that $M$. quadridentata could eat plankton, fish, shrimp, mollusc, and mangrove leaves. This behavior was due to $M$. quadridentata that identified as an omnivorous-scavenger animal (Rosmaniar 2008).

The omnivorous-scavenger animal was a consumption classification for animals that have the capability to obtain chemical energy and nutrients from materials originating from plant and animal, even the dead ones. If microplastics could be ingested into the crab, probably the prey of this mangrove crab has contaminated with microplastics. Besides sourced from it's prey, microplastic could get into mangrove crab by the sea water that inhaled through the respiratory system. Sea water that already contaminated with microplastics could easily get into the body through the gills and trapped in crab body (Brennecke et al. 2015).

Piarulli et al. (2019) reported that crab Carcinus aestuarii in the Adriatic Sea contained 1 - 117 particle microplastic in the digestive tract. We found a number of microplastic three times higher, maybe our crab live in the more polluted area, because the Pramuka Island is inhabited by dense fishermen population.

Known from several studies before, more than 250 taxa of marine animals, including 32 species of marine invertebrates, polluted by microplastics in the ocean (Goldstein \& Goodwin 2013). Microplastics was known to be able to get into the body of some crustaceans such as Nephrops norvegicus (Murray \& Cowie 2011), Talitrus saltator (Ugolini et al. 2013), Crangon crangon (Devriese et al. 2015), and Eriocheir sinensis (WójcikFudalewska et al. 2016). In the study that was done by Welden and Cowie (2016) about the long-term effects of microplastics exposure to prawn Nephrops norvegicus, known that microplastics exposured to the prawn's feed for approximately 8 months could causing a decrease in the body's nutrients of prawn. Moreover, exposure of microplastics in the long-term could reduce the stability of the population and affects the quality of life of Nephrops norvegicus. Decrease of nutrients that occurs could be caused due to the damage of the digestive tract by exposure microplastics which affect the efficiency of digestion. Watts et al. (2015) investigated effect of microfibers in the crab Carcinus maenas. They found that the crab showed reduced food consumption and a significant reduction in energy available for growth. Effect of the microfiber in the Pacific mole crabs (Emerita analoga) had increased adult crab mortality, and decreased retention of egg clutches, and varied embryonic development rates (Horn et al. 2020). According to Figures 4 and 5, it was known that microplastic abundance in snails and crab has a positive correlation with body weight. This is because the heavier the animal's bodies, more food to eat.

\section{CONCLUSION}

Periwinkle snail L. scabra and crab M. quadridentata in mangrove ecosystem of Pramuka Island, proven to be contaminated by microplastic. The microplastic type was found in fiber, film, fragment, and granule. The fiber type has the highest abundance. There was a positive correlation between microplastic abundance with the body weight of snail and crab. 


\section{ACKNOWLEDGEMENTS}

The authors would like to thank Universitas Indonesia for the PITTA (Publikasi Internasional Terindeks untuk Tugas Akhir) 2018 grant given to Mufti P. Patria to fund and support our entire research.

\section{REFERENCES}

Alfaro, A.C. 2007. Diet of Littoraria scabra while vertically migrating on mangrove trees: Gut content, fatty acid, and stable isotope analyses. Estuarine, Coastal and Shelf Science 79(4): 718-726.

Al-Hamra, A.J. \& Patria, M.P. 2019. Microplastic in Gonggong snails (Laevistrombus turturella) and sediment of Bintan Island, Kepulauan Riau Province, Indonesia. AIP Conference Proceedings 2202(1): 020079.

Andrady, A.L. 2011. Microplastics in the marine environment. Marine Pollution Bulletin 62(8): 1596-1605.

Brennecke, D., Duarte, B., Paiva, F., Caçador, I. \& CanningClode, J. 2016. Microplastics as vector for heavy metal contamination from the marine environment. Estuarine, Coastal and Shelf Science 178(5): 189-195.

Browne, M.A., Niven, S.J., Galloway, T.S., Rowland, S.J. \& Thomson, R.C. 2013. Microplastic moves pollutants and additives to worm, reducing functions linked to health and biodiversity. Current Biology 23(23): 2388-2392.

Browne, M.A., Crump, P., Niven, S.J., Teuten, E., Tonkin, A., Galloway, T. \& Thompson, R.C. 2011. Accumulation of microplastic on shorelines worldwide: Source and sinks. Environment Science Technology 45(21): 9175-9179.

Cole, M., Lindeque, P., Fileman, E., Halsband, C., Goodhead, R., Moger, J. \& Galloway, T.S. 2013. Microplastic ingestion by zooplankton. Environmental Science \& Technology 47(12): 6646-6655.

CSIRO. 2014. Distribution and Fate of Marine Debris. https:// www.csiro.au/en/Research/OandA/Areas/Marine-resourcesand-industries/Marine-debris. Accessed on 2 March 2018.

Devriese, L.I., van der Meulen, M.D., Maes, T., Bekaert, K., Paul-Pont, I., Frère, L., Robbens, J. \& Vethaak, A.D. 2015. Microplastic contamination in brown shrimp (Crangon crangon, Linnaeus 1758) from coastal waters of the Southern North Sea and Channel area. Marine Pollution Bulletin 98(1-2): 179-187.

Dias, B.F.D.S. \& Lovejoy, T.E. 2012. Impacts of marine debris on biodiversity: Current status and potential solutions. $C B D$ Technical Series 67: 11-26.

Fathoniah, I. 2013. Kelimpahan mikroplastik pada kerang hijau Perna viridis, air, dan sedimen di kamal muara. Universitas Indonesia, Thesis (Unpublished)

Fitri, S. \& Patria, M.P. 2019. Microplastic contamination on Cerithidea obtusa (Lamarck 1822) in Pangkal Babu Mangrove Forest Area, Tanjung Jabung Barat District, Jambi. AIP Conference Proceedings 2168(1): 020075.

Goldstein, M.C. \& Goodwin, D.S. 2013. Gooseneck barnacles (Lepas spp.) ingest microplastic debris in the North Pacific Subtropical Gyre. Peer J. 1: e184.

Green, D.S. 2016. Effects of microplastics on European flat oysters, Ostrea edulis and their associated benthic communities. Environmental Pollution 216: 95-103.
Gregory, M.R. 1996. Plastic 'scrubbers' in hand cleansers: A further [and minor] source for marine pollution identified. Marine Pollution Bulletin 32(12): 867-871.

Hapitasari, D.N. 2016. Analisis kandungan mikroplastik pada pasir dan ikan demersial: Kakap [Lutjanus sp.] dan kerapu [Epinephelus sp.] di Pantai Ancol, Palabuhanratu dan Labuan. IPB University, Thesis (Unpublished).

Holmes, L.A. 2013. Interactions of trace metals with plastic production pellets in the marine environment. Marine Chemistry 167: 25-32.

Horn, D.A., Granek, E.F. \& Steele, C.L. 2020. Effects of environmentally relevant concentrations of microplastic fibers on Pacific mole crab (Emerita analoga) mortality and reproduction. Limnology and Oceanography Letters 5(1): 74-83.

Kementerian Koordinator Maritim. 2017. KEMENKO Maritim Angkat $142 \mathrm{~kg}$ Sampah dari Dasar Laut Pulau Seribu. https:// maritim.go.id/kemenko-maritim-angkat-142-kg-sampah-didari-dasar-laut-pulau-seribu/. Accessed on 2nd March 2018.

Lembaga Ilmu Pengetahuan Indonesia (LIPI). 2009. Bom Waktu Pencemaran Teluk Jakarta dan Pulau Seribu. http:// lipi.go.id/berita/bom-waktu-pencemaran-teluk-jakarta-danpulau-seribu-/3744. Accessed on 9th March 2018.

Lie, S., Suyoko, A., Effendi, A.R., Ahmada, B., Aditya, H.W., Sallima, I.R., Arisudewi, N.P., Hadid, N.L., Rahmasari, N. \& Reza, A. 2018. Measurement of microplastic density in the Karimunjawa National Park, Central Java, Indonesia. Ocean Life 2(2): 54-58.

Murray, F. \& Cowie, P. 2011. Plastic contamination in the decapods crustacean Nephrops norvegicus (Linnaeus, 1758). Marine Pollution Bulletin 62(6): 1207-1217.

Ningrum, E.W. \& Patria, M.P. 2019. Ingestion of microplastics by anchovies from east Lombok Harbour, Lombok Island, Indonesia. AIP Conference Proceedings 2120: 040002.

Piarulli, S., Scapinello, S., Comandini, P., Magnusson, K., Granberg, M., Wong, J.X.W., Sciutto, G., Prati, S., Mazzeo, R., Booth, A.M. \& Airoldi, L. 2019. Microplastic in wild populations of the omnivorous crab Carcinus aestuarii: A review and a regional-scale test of extraction methods, including microfibres. Environmental Pollution 251: 117-127.

Pirc, U., Vidmar, M., Mozer, A. \& Krzan, A. 2016. Emissions of microplastic fibers from microfiber fleece during domestic washing. Environment Science Pollution Research 23(21): 22206-22211.

Rosmaniar. 2008. Kepadatan dan distribusi kepiting bakau (scylla spp) serta hubungannya dengan faktor fisik kimia di periaran pantai labu kabupaten deli serdang. Universitas Sumatera Utara, Master's Thesis (Unpublished).

Sahwan, F.L. 2004. Strategi pengelolaan sampah di kepulauan Seribu. Jurnal Teknologi Lingkungan 5(1): 12-16.

Tanaka, K. \& Takada, H. 2016. Microplastic fragments and microbeads in digestive tracts of planktivorous fish from urban coastal waters. Science Report 6: 34351.

Teuten, E.L., Saquing, J.M., Knappe, D.R., Barlaz, M.A., Jonsson, S., Björn, A., Rowland, S.J., Thompson, R.C., Galloway, T.S., Yamashita, R. \& Ochi, D. 2009. Transport and release of chemicals from plastics to the environment 
and to wildlife. Philosophical Transactions of the Royal Society B 364: 2027-2045.

Tupan, C.I. 2009. Tingkah laku pergerakan gastropoda Littoraria scabra pada pohon Mangrove Sonneratia alba di Perairan Pantai Tawiri Pulau Ambon. Triton 5(1): 28-33.

Ugolini, A., Ungherese, G., Ciofini, M., Lapucci, A. \& Camaiti, M. 2013. Microplastic debris in sandhoppers. Estuary Coastal and Shelf Science 129: 19-22.

Watts, A.J.R., Urbina, M.A., Corr, S., Lewis, C. \& Galloway, T.S. 2015. Ingestion of plastic microfibers by the crab Carcinus maenas and its effect on food consumption and energy balance. Environmental Science \& Technology 49(24): 14597-14604.

Welden, N.A.C. \& Cowie, P.R. 2016. Longterm microplastic retention causes reduced body condition in the langoustine Nephrops norvegicus. Environmental Pollution 218: 895-900.
Wójcik-Fudalewska, D., Normant-Saremba, M \& Anastácio, P. 2016. Occurrence of plastic debris in the stomach of the invasive crab Eriocheir sinensis. Marine Pollution Bulletin 113(1-2): 306-311.

Wright, L.C., Thompson, R.C. \& Galloway, T.S. 2013. The physical impacts of microplastics on marine organism. Environment Pollution 178: 483-492.

Department of Biology

Universitas Indonesia

Kampus FMIPA-UI, Depok 16424

Indonesia

*Corresponding author; email: mpatria@sci.ui.ac.id

Received: 15 January 2020

Accepted: 7 May 2020 